\title{
Az Alkotmánybíróság fontosabb döntései 2019. április 1-je és május 31-e között ${ }^{1}$
}

\section{SZABÓ ATTILA}

Az Alkotmánybiróság 2019 második negyedévében 93 döntést hozott, amelyek közül 20 érdemi határozat volt. Az Alkotmánybiróság normakontrollos hatásköreiben egy esetben mondta ki jogszabály alaptörvény-ellenességét és semmisitette meg a jogszabályt. A vizsgált idöszakban egy esetben mondott ki jogalkotói mulasztásban megnyilvánuló alaptörvény-ellenességet és egy esetben alkotmányos követelményt.

Az Alkotmánybiróság legtöbbet gyakorolt hatásköre továbbra is az alkotmányjogi panasz eljárás, amelyek közül kiemelkedik a bírói itéletekkel szemben elöterjesztett panasz. Ebben a hatáskörében eljárva a második negyedévben hat bírói döntést semmisitett meg.

A cikk öt fontosabb döntést foglal össze a vizsgált időszakból. A környezetvédelmi hatósági rendszer átalakitásával kapcsolatban a 12/2019. (IV. 8.) AB határozatban az Alkotmánybíróság kimondta, hogy Alaptörvénybe ütközik, ha egy közigazgatási eljárásban első- és másodfokon is ugyanaz a szerv jár el. A véleménynyilvánitás szabadságának sérelmét vizsgálva a 14/2019. (IV. 17.) AB határozatban az Alkotmánybíróság megsemmisitette a járásbiróság itéletét, amelyben köztisztasági szabálysértés miatt szankcionált egy olyan cselekményt, amely a véleménynyilvánitás szabadságának védelmi körébe tartozik. A 15/2019. (IV. 17.) AB határozatában az Alkotmánybiróság a Munka Törvénykönyve egyes módositásainak közjogi érvénytelenségét vizsgálva fontos megállapitásokat tett az obstrukció intézményével kapcsolatban. A 3089/2019. (IV. 26.) AB határozatában arról döntött az Alkotmánybíróság, hogy a közveszéllyel fenyegetés látszatát keltő cselekmények nem tartoznak a véleménynyilvánitás szabadságának oltalma alá. A 19/2019. (VI. 18.) AB határozatban a közterületen élést szabálysértéssé nyilvánitó norma vizsgálatakor az Alkotmánybíróság kimondta: az elesettek védelmére vonatkozó állami kötelezettségböl a hatóságok és a bíróság számára az a kötelezettség adódik, hogy az érintett személyekkel szemben az állami gondoskodás érvényesitőjeként járjanak el, annak nyilvánvalóvá tétele mellett, hogy a közterületen élés alkotmányos tilalmának érvényesülése mind az érintett egyén, mind pedig a társadalom közös érdeke.

1 Az összeállításban segítségemre volt Dr. Németh Ágnes tanácsadó. 


\section{Significant Decisions of the Constitutional Court between 1 April and 31 May 2019}

The Constitutional Court (hereinafter: CC) made 93 decisions in the first quarter of 2019. From these, 20 decisions were on the merits, meanwhile the others were mainly rejections on formal grounds. In the competences of norm control, the CC has annulled one legal regulation, it declared one constitutional requirement and one legislative omission.

The mostly practiced competence of the CC is still the constitutional complaint procedure, mainly the one against judicial decisions. In its competence, the Court annulled six judicial decisions in the second quarter of 2019.

The Article summarises five significant decisions of the CC from the second quarter of the year. The CC ruled that when the institutional frame of the environmental protection authorities is changed, it is contrary to the Fundamental Law if the first grade and the second grade authority is the same [CC decision 12/2019 (IV. 8.) $A B]$. The Court ruled that the removable paintings made on the asphalt in order to raise the attention of the authorities for the omitted reparation falls within the protection of the free speech clause and therefore it cannot be sanctioned [CC decision 14/2019 (IV. 17.) AB]. The Court has made several important statements about the obstruction when examining the invalidity under public law of certain amendments of the Labour Code [CC decision 15/2019 (IV. 17.) AB]. The Court ruled that communicative actions that have a threatening character and that may cause public danger do not fall within the protection scope of the free speech clause [CC decision 3089/2019 (IV. 26.) AB]. Lately the Court, when examining the regulation on the prohibition of living on the streets has declared that it is the obligation of the State to help those in need, and from this obligation the State should proceed as a social caretaker, therefore the constitutional prohibition of dwelling on the streets should be counterbalanced by the obligatory institutional care for those without home.

\section{A)}

Az Alkotmánybíróság 2019 második negyedévében 93 döntést hozott, amelyek közül 20 érdemi határozat, míg 73 - többnyire a befogadási eljárás során hozott - viszszautasító végzés. ${ }^{2} \mathrm{Az}$ érdemi határozatok - az Alkotmánybíróság hatásköreire figyelemmel - a következők szerint oszlanak meg. Az Alkotmánybíróság a vizsgált időszakban egy esetben utólagos normakontroll indítvány [az Alkotmánybíróságról szóló 2011. évi CLI. törvény (a továbbiakban: Abtv.) 24. \$-a] alapján (az országgyűlési képviselők egynegyedének indítványára) járt el. Az Abtv. 25. \$-a szerinti bírói kezde-

2 A statisztikai adatok alapját a 2019. április 1. és 2019. június 30. között az Alkotmánybiróság Határozatai címü közlönyben közzétett döntések adják. 
ményezés alapján négy esetben hozott határozatot. Az Alkotmánybíróság legtöbbet gyakorolt hatáskörében, alkotmányjogi panaszeljárásban összesen tizenöt érdemi határozatot hozott, amelyből tizennégy - az Abtv. 27. \$ alapján - bírói ítélettel szemben elöterjesztett panasz volt, egy pedig - az Abtv. 26. \$ (1) bekezdése szerinti - bírói ítéletben alkalmazott normával szemben előterjesztett panasz.

A határozatokban megállapított jogkövetkezményeket tekintve az alábbi döntések születtek. Jogszabályi rendelkezés alaptörvény-ellenességének megállapítására és megsemmisítésére a második negyedévben egy esetben került sor. Bírói döntést alaptörvény-ellenesség miatt hat esetben semmisített meg az Alkotmánybíróság. Egy esetben a jogszabály általános alkalmazási tilalmát mondta ki. Mulasztásban megnyilvánuló alaptörvény-ellenességet egy ügyben állapított meg, egy alkalommal pedig alkotmányos követelményt mondott ki. Az indítványokat határozatban tizenkét esetben utasította el, hetvenhárom esetben pedig visszautasító végzéssel zárta le az eljárást.

A bírói döntések felülvizsgálatakor, azok megsemmisítése esetén a következő alapjogok védelme érdekében állapította meg az Alkotmánybíróság az alaptörvényellenességet a második negyedévben: közérdekű adatok megismeréséhez való jog [Alaptörvény VI. cikk (3) bekezdés], véleménynyilvánítás szabadsága [IX. cikk], tisztességes eljáráshoz való jog [Alaptörvény XXVIII. cikk (1) bekezdés].

A testület normakontrollos hatáskörében eljárva, a jogszabály megsemmisítésekor az Alaptörvény XXVIII. cikk (7) bekezdése szerinti jogorvoslati jogba való ütközést állapított meg.

Az alkotmányos követelményt az emberhez méltó lakhatás feltételeinek biztosítására való törekvést előíró XXII. cikk (1) és (3) bekezdéseiből vezette le.

Mulasztásban megnyilvánuló alaptörvény-ellenességet pedig a B) cikk (1) bekezdés sérelme miatt mondta ki.

\section{B)}

Az alapjogok védelmének és a magyar alkotmányjog dogmatikájának szempontjából, időrendi sorrendben, a következő döntések részletes ismertetése szükséges.

\section{Alaptörvénybe ütközik, ha mind elsö-, mind másodfokon ugyanaz a kormányhivatal jár el}

1.1. Az Alkotmánybíróság - bírói kezdeményezés alapján - a 12/2019. (IV. 8.) AB határozatában a jogorvoslathoz való jog sérelme miatt megsemmisítette az egyes központi hivatalok és költségvetési szervi formában működő minisztériumi háttérintézmények felülvizsgálatával összefüggő jogutódlásáról, valamint egyes közfeladatok átvételéről szóló 378/2016. (XII. 2.) Korm. rendelet 43. \$ (1) bekezdését.

Az Alkotmánybíróság kimondta: a jogalkotó nem kötelezheti az elsőfokú határozatot hozó közigazgatási szervet a másodfokú eljárás lefolytatására is, kivéve, ha az érin- 
tett közigazgatási szerven belül működik egy erre hatáskörrel rendelkező magasabb fórum. A testület megsemmisítette egy kormányrendelet azon rendelkezését, amely egyes ügyekben az első fokon eljáró Pest Megyei Kormányhivatalt jelölte ki a fellebbezés elbírálására jogosult szervként is.

1.2. A Fővárosi Közigazgatási és Munkaügyi Bíróság egyik bírája fordult indítványnyal az Alkotmánybírósághoz. A bíró álláspontja szerint sérti a jogorvoslathoz való jogot, hogy az előtte folyamatban lévő, hulladékgazdálkodással kapcsolatos ügyben a Pest Megyei Kormányhivatal hozott első fokon döntést, majd a jogszabály előírásainak megfelelően a másodfokú eljárást is ugyanezen hatóság folytatta le. Az indítványozó bíró kezdeményezte, hogy az Alkotmánybíróság az egyes központi hivatalok és költségvetési szervi formában működő minisztériumi háttérintézmények felülvizsgálatával összefüggő jogutódlásáról, valamint egyes közfeladatok átvételéről szóló 378/2016. (XII. 2.) Korm. rendelet (a továbbiakban: Korm. rendelet) 43. $\mathbb{S}$ (1) bekezdésének alaptörvény-ellenességét állapítsa meg, továbbá rendelje el annak általános alkalmazási tilalmát.

Az indítványozó szerint a támadott rendelkezés sérti az Alaptörvény XXVIII. cikk (7) bekezdésében foglalt jogorvoslathoz való jogot, mivel a Korm. rendelet értelmében azon ügyekben, amelyekben korábban a Pest Megyei Kormányhivatal hozott első fokon döntést, a módosítás során folyamatban lévő eljárásoknál a másodfokú eljárást ugyanezen hatóság folytatta le. Az indítványozó szerint a jogorvoslathoz való jog sérelme egyben az Alaptörvény B) cikk (1) bekezdésének sérelmét is eredményezi, hiszen a jogállamiság követelményével ellentétes, hogy az elsőfokú döntés ellen benyújtott fellebbezést ugyanazon hatóság - sőt, esetenként akár ugyanaz a személy - bírálja el.

1.3. Az Alkotmánybíróság kiemelte: a jogorvoslathoz való jog olyan alkotmányos alapjog, amely azt kívánja meg, hogy az érintett jogát vagy jogos érdekét befolyásoló érdemi határozat felülvizsgálata érdekében más szervhez, vagy azonos szerv magasabb fórumához fordulhasson. Az Alaptörvény minden esetben megköveteli, hogy a jogorvoslati jog nyújtotta jogvédelem hatékony legyen, vagyis ténylegesen érvényesüljön, és képes legyen a döntés által okozott sérelem orvoslására.

Az Alkotmánybíróság megítélése szerint a közigazgatási hatáskörök észszerűsítése, valamint a költséghatékonyan működő szolgáltató állam megteremtése szükségessé teheti a közigazgatási intézményrendszer átalakítását. Az Országgyủlés és a kormány széles körű szervezet-átalakítási jogosítványokkal rendelkezik, azonban ezek nem korlátlanok, hanem csak az Alaptörvény keretei között érvényesíthetők. az Alaptörvény XXVIII. cikk (7) bekezdéséből nem vezethető le a közigazgatás szervezetrendszerén belüli fellebbezés mint valódi jogorvoslat biztosításának kötelezettsége, ám azt az Alaptörvény nem is tiltja meg. Ezért abban az esetben, ha a jogalkotó úgy dönt, hogy teremt ilyen valódi jogorvoslatnak minősülő fellebbezési lehetőséget, úgy arra ugyancsak vonatkozniuk kell az Alaptörvény XXVIII. cikk (7) bekezdéséből fakadó alaptörvényi követelményeknek, függetlenül attól, hogy ezt követően a bíró- 
sághoz fordulás lehetősége minden esetben biztosított. Ebből következően a környezetvédelmi hatósági ügyekben a közigazgatási szervezetrendszeren belül biztosítandó fellebbezés lehetősége is az Alaptörvény XXVIII. cikk (7) bekezdésének hatálya alá tartozik.

A jogorvoslathoz való jogból nem következik szükségszerűen az, hogy egy, az Alaptörvény XXVIII. cikk (7) bekezdése hatálya alá tartozó fellebbezési eljárásban minden esetben az első fokon eljáróhoz képest más szervnek kell biztosítania a jogorvoslatot, hanem adott esetben ugyanazon szerv magasabb fórumának eljárása is összeegyeztethető az Alaptörvénnyel. A jogorvoslathoz való jog lényegi tartalmával ellentétes ugyanakkor az a szabályozás, amely valamely hatósági döntéssel szemben a közigazgatás intézményrendszerén belül oly módon kíván fellebbezés keretében valódi jogorvoslati lehetőséget biztosítani, hogy a jogorvoslati fórum sem más szervnek, sem ugyanazon szerv magasabb fórumának nem minősíthető. Ha pedig egy jogszabály úgy rendelkezik, hogy mind első-, mind pedig másodfokon ugyanaz a kormányhivatal - a jelen esetben ugyanaz a döntéshozó személy - járjon el, akkor ez a szabályozás sem a más szervhez, sem pedig az azonos szerv magasabb fórumához fordulás alaptörvényi követelményét nem teljesíti.

A testület ezért kimondta: a támadott szabályozás ellentétes a jogorvoslathoz való joggal, mivel egyes környezetvédelmi tárgyú ügyekben folytatott fellebbezési eljárások esetében a szabályozás nem teljesíti a más szervhez, vagy az azonos szerv magasabb fórumához fordulás követelményét. Az Alkotmánybíróság a támadott rendelkezést megsemmisítette, és egyes ügyekben alkalmazási tilalmat rendelt el.

\section{A véleménynyilvánítás alkotmányosan védett körébe sorolható minden olyan kommunikációs üzenetet hordozó cselekmény, amely a magántulajdon tárgyát nem, vagy csak a tulajdonos beleegyezésével érinti, és köztulajdon tárgyában pedig nem okoz állagsérelmet}

2.1. Az Alkotmánybíróság - alkotmányjogi panasz alapján indult eljárásban a 14/2019. (IV. 17.) AB határozatában a véleménynyilvánítás szabadságának megsértése miatt megsemmisítette a Szombathelyi Járásbíróság köztisztasági szabálysértés tárgyában hozott végzését.

2.2. Az alkotmányjogi panasz indítványozói színes festékkel festették be egy járdaszakasz berepedezett részeit, részben balesetmegelőzési céllal, részben azért, hogy felhívják a hatóság és a közvélemény figyelmét a burkolat hibáira. A szabálysértési hatóság az indítványozókat köztisztasági szabálysértés elkövetése miatt figyelmeztetésben részesítette.

Az indítványozók a hatóság döntésével szemben kifogással éltek, a járda felületét ugyanis nem szennyezték be, az általuk használt vízben oldódó festék könnyen eltávolítható, és magatartásuk nem volt más, mint a szabad véleménynyilvánításuk, amellyel egy hatósági mulasztásra hívták fel a közvélemény figyelmét. Utaltak arra, 
hogy míg a vonatkozó jogszabályok szerint a járdát a meghibásodást követő egy héten belül ki kellene javítani. Az eljáró bíróság ezt követően arra a következtetésre jutott, hogy az indítványozók magatartása, amellyel véleményük kifejezésére más tulajdonát a tulajdonos hozzájárulása nélkül vették igénybe, veszélyes volt a társadalomra, mivel sértette a tulajdonos rendelkezési jogát. Az indítványozók a bíróság jogerős végzésével szemben fordultak az Alkotmánybírósághoz.

Álláspontjuk szerint a bírói döntés sérti az Alaptörvény IX. cikk (1) bekezdésben biztosított szabad véleménynyilvánításhoz való jogukat, illetve a X. cikk (1) bekezdésben biztosított művészeti alkotás szabadságához füződő jogukat.

\subsection{Az Alkotmánybíróság megalapozottnak találta az indítványt}

Az Alkotmánybíróság megállapította, hogy a véleménynyilvánítás alkotmányosan védett körébe sorolható minden olyan kommunikációs üzenetet hordozó cselekmény, amely a magántulajdon tárgyát nem, vagy csak a tulajdonos beleegyezésével érinti, és köztulajdon tárgyában pedig nem okoz állagsérelmet.

Az Alaptörvény IX. cikk (1) bekezdésében foglalt véleménynyilvánítás jogának a hatálya, vagyis a „véleménynyilvánítás” fogalma normatív természetủ, amely ugyan nem öleli fel a véleményalkotás valamennyi megnyilvánulását, viszont egyúttal magában foglal a szóbeli vagy írásbeli kommunikáción túli aktusokat is. A véleménynyilvánító nemcsak szavakkal, hanem például képek, szimbólumok használatával vagy ruhadarabok viselésével is megoszthatja gondolatait.

A véleménynyilvánítás alapjoga hatályának meghatározásakor elsődlegesen a demokratikus társadalmi kommunikációban való részvétel szempontja nyújt segítséget. Eszerint azok a kommunikatív aktusok állnak kapcsolatban a szólásszabadsággal, amelyekkel az érintettek a nyilvános társadalmi párbeszédben vesznek részt. Ebben azonban a polgárok sokszínủbb módon vehetnek részt, mint a hagyományos értelemben vett beszéd vagy írás, ezért a véleménynyilvánítás jogának a hatálya is szélesebb a verbális kifejezéseknél.

Egy konkrét cselekmény vonatkozásában az Alkotmánybíróságnak nem feladata annak eldöntése, hogy a szabálysértési hatóságok, illetve az eljáró bíróságok mely cselekményeket tekintik társadalomra veszélyesnek. Azt azonban vizsgálnia kell az Alkotmánybíróságnak, hogy a társadalomra veszélyesség megállapítása nem eredményezi-e egy védett alapjog gyakorlásának alkotmányellenes korlátozását.

E tekintetben az Alkotmánybíróságnak elsődlegesen arra kellett választ adnia, hogy az indítványozók cselekménye, azaz a betöredezett járda repedéseinek színes festékkel való befestése, tekinthető-e a véleménynyilvánítás alkotmányosan védett tárgykörébe tartozónak, és amennyiben igen, akkor azt az eljáró bíróság figyelembe vette-e a cselekmény társadalomra való veszélyességének megítélése során.

A közterületnek minősülő út- vagy járdaszakaszon könnyen eltávolítható festékkel elhelyezett feliratok, színezések ugyanis minősülhetnek a véleménynyilvánítás jogának hatálya alá eső szimbolikus szólásnak. Ennek megítélése során elsősorban arra kell figyelemmel lenni, hogy a véleményközlés személyes szándékán túl az adott 
cselekmény (például felfestett felirat vagy színezés) objektív módon is alkalmasnak tekinthető eszköze, közvetítője lehet-e gondolatok közlésének. Amennyiben ugyanis erre igenlő választ tudunk adni, akkor ezen cselekményt a véleménynyilvánítás körébe tartozó cselekménynek kell tekintenünk.

Annak megítélése, hogy a véleménynyilvánítás szabadságának hatálya alatt vizsgálandó cselekményről, avagy vandalizmusról van-e szó, a bíróságok feladata. Jelen ügyben a cselekmény mind a „véleménynyilvánító” személy szubjektív szándéka, mind az objektív értékelés szerint a nyilvánosság előtt értelmezhető közlés volt. Az Alkotmánybíróság megállapította: a bíróság nem értékelte megfelelően az indítványozók cselekményét, és aránytalan módon korlátozta az indítványozók véleménynyilvánításhoz való jogát. Az eljáró rendes bíróság arra sem volt figyelemmel, hogy a cselekmény társadalomra veszélyessége nem állapítható meg.

A fenti indokok miatt az Alkotmánybíróság megállapította, hogy a bíróság végzése alaptörvény-ellenes, ezért azt megsemmisítette.

\section{Nem állapitható meg közjogi érvénytelenség a Munka Törvénykönyvének módosítása és a közigazgatási bíróságokról szóló törvény kapcsán}

3.1. Az Alkotmánybíróság a 15/2019. (IV. 17.) AB határozatában elutasította az országgyülési képviselők több mint egynegyedének azon indítványait, amelyekben az Országgyűlés 2018. december 12-i ülésnapján elfogadott egyes törvények (a munkaerő-kölcsönzés minimális kölcsönzési díjával összefüggő egyes törvények módosításáról szóló 2018. évi CXVI. törvény egésze, továbbá a közigazgatási bíróságokról szóló 2018. évi CXXX. törvény egésze, valamint a közigazgatási bíróságokról szóló törvény hatálybalépéséről és egyes átmeneti szabályokról szóló 2018. évi CXXXI. törvény egésze) közjogi érvénytelenségét állították, azok elfogadási körülményei miatt.

3.2. Az országgyűlési képviselők A munka törvénykönyve módosított rendelkezései, továbbá a közigazgatási bíróságokról szóló törvény alaptörvény-ellenességére hivatkoztak azzal összefüggésben, hogy az ülésnapon az Országgyűlés elnöke és a levezető elnök - arra való hivatkozással, hogy megakadályozták a pulpitusra való feljutását - nem a pulpitusról vezette az említett törvényekről való szavazást is magában foglaló ülést, a szolgálatban lévő jegyzők közül egyik sem tartozott ellenzéki képviselőcsoporthoz, valamint a szavazási rendszer, mivel az elnök saját szavazókártyáját sem helyezhette be a pulpituson, kártya nélküli üzemmódban működött. Az indítványozók álláspontja szerint az ülést levezető elnök nem a vonatkozó jogszabályok alapján járt el, amely a jogsértő eljárásban elfogadott törvény közjogi érvénytelenségét eredményezi. Az Alkotmánybíróság következetes gyakorlata szerint ugyanis [109/2008. (IX. 26.) AB határozat, 6/2013. (III. 1.) AB határozat] „közjogi érvénytelenséget eredményez az Országgyűlés müködésére vonatkozó olyan szabály megsértése, amely alaptörvényi alappal rendelkezik". 
3.3. Az Alkotmánybíróság kiemelte: történeti alkotmányunk egyik legfontosabb vívmánya az Országgyűlés intézményének létrejötte és közjogi szerepe. Az Országgyűlés törvényes és alkotmányos működése a jogállamiság és az alkotmányos hatalomgyakorlás egyik kulcsa Magyarországon. Az Országgyülés zavartalan müködésének biztosítása és méltóságának megőrzése az Országgyűlés elnökének joga, és egyben kötelezettsége is.

A szakirodalomban obstrukciónak nevezett magatartások azok, amikor az országgyűlésben kisebbségbe került politikai erők egyes politikai céljaik elérése érdekében rendeltetésellenes módon gyakorolják egyébként jogszerűen rendelkezésükre álló lehetőségeiket (például beszédjogukkal a tárgyalás időbeli elhúzását célzó módon élnek). Az Alkotmánybíróság szerint a hazai alkotmányos gyakorlat és a nemzetközi gyakorlat tükrében - megfelelő garanciák érvényesülése esetén, továbbá a konkrét szabály, vagy eset körülményeit gondosan mérlegelve - egyaránt igazolható lehet az egyes parlamentek arra irányuló törekvése, hogy a zavartalan és demokratikus müködés biztosítása érdekében az obstrukciót megakadályozzák, vagy az ilyen célzatú képviselői magatartásokat keretek között tartsák, esetleg fegyelmi előírásokkal szankcionálják. Nem tekinthetők viszont obstrukciónak azok a magatartások, amelyek formai értelemben sem nevezhetőek jogszerünek. Ezek révén ugyanakkor elöállhat olyan jogellenes helyzet, amikor a rendeltetésszerü müködés helyreállítása azonnali megoldást követel, de adott esetben sem a „rendes” eljárásra, sem pedig a fegyelmirendészeti jellegű intézkedésekre vonatkozó szabályokban arra nézve konkrét előírás nem található.

3.4. Az indítványban három szempontból állították a törvénymódosítás közjogi érvénytelenségét. Az Alkotmánybíróság e szempontokra az alábbi válaszokat adta.

\subsection{1. Ülésvezetés a patkóból, a feljutás megakadályozása, rendészeti jogkör}

Az Országgyűlés 2018. december 12-i ülésnapjának jegyzőkönyvéből kiderül, hogy ellenzéki képviselőcsoportokhoz tartozó, illetve független képviselők az utat elállva, fizikailag ellehetetlenítették a feljutást az elnöki emelvényre. A házszabályi rendelkezések szövegéből azonban nem következik, hogy az ülés ne lenne vezethető máshonnan, mint az elnöki székből, amennyiben az ülésvezetés a garanciális jelentőségủ eljárási szabályoknak egyébként megfelel, mivel a pulpitus használata alapvetően praktikus célokat szolgál.

\subsubsection{A jegyzők közreműködése}

Az Országgyủlésről szóló törvény alapján az üléseken egyidejűleg kettő, lehetőleg egy kormánypárti és egy ellenzéki képviselőcsoporthoz tartozó jegyző teljesít szolgálatot. A vizsgált esetben a jegyzők kijelölésére egyrészt nem visszaélésszerűen, hanem kényszerítő okok következtében került sor, másrészt pedig annak módja sem volt a vonatkozó jogszabályok által kizárt, így az nem tekinthető a garanciális tartalmú 
előírás megsértésének, ezáltal közjogi érvénytelenség megállapítását sem eredményezheti.

\subsubsection{Kártya nélküli üzemmód}

A szavazások lebonyolításának az indítványozók által kifogásolt módja kapcsán az Alkotmánybíróság megállapította, hogy a vonatkozó eljárási szabályok egyrészt nem írják elő a gépi szavazások „kártyás üzemmódban” történő lebonyolítását, másrészt pedig a demokratikusan megválasztott országgyűlési képviselők a népszuverenitás gyakorlói, akik felelősséggel tartoznak azért, hogy megfeleljenek - többek között - a személyes közreműködésre vonatkozó elvárásnak. Ily módon a képviselő felelőssége, hogy szavazáskor más képviselőhöz tartozó - akár a kártyájához, akár az üléshelyéhez rendelt - berendezésen ne nyomjon gombot, az esetleges ilyen magatartás mára már szankcionálhatóvá is vált. Az Országgyűlés üléséről készült, hitelesített jegyzőkönyv szerint az Országgyűlés 2018. december 12-i ülése határozatképes volt, az indítványokban érintett három törvény elfogadásánál a szükséges számú szavazatot leadták. Ezen túlmenően, az indítványok a szavazások eredményével kapcsolatban csupán érdemi elbírálásra alkalmatlan felvetéseket, lehetőségeket fogalmaztak meg.

Mindezek alapján az Alkotmánybíróság a támadott rendelkezések alaptörvény-ellenességének megállapítására és megsemmisítésére vonatkozó indítványokat elutasította.

Az Alkotmánybíróság az eset kapcsán hangsúlyozta azt is, hogy bár az a polgári jogi alapelv, miszerint saját felróható magatartására előnyök szerzése végett senki nem hivatkozhat, kifejezett alkotmányjogi tételként jogrendszerünkben nem jelenik meg, mégis a jogok jóhiszemü és rendeltetésszerü gyakorlásának elve az egész jogrendszert áthatja. Az a magatartás, amely az Országgyűlés döntéshozatali eljárásának jogszerütlen eszközökkel történő ellehetetlenítésére irányul, végső fokon az állam alkotmányos működését veszi célba. Az ilyen magatartás alaptörvény-ellenes. Ilyen magatartást a jog nem védhet, ahhoz jogszerzés nem társulhat, mert ez kifordítaná magából a jogállamot. Az Alkotmánybíróság mint az Alaptörvény védelmének legfőbb szerve, ilyen törekvésekkel szemben - mivel a parlamentre épülő alkotmányos berendezkedésnek nincsen alkotmányos alternatívája - nem lehet közömbös.

\section{A közbiztonság fenntartásának alkotmányosan védett értékét sértö, külső szemlélö számára nem azonositható jelentéssel bíró kommunikációs cselekmény nem tartozik a véleménynyilvánítási szabadság védelmi körébe.}

4.1. Az Alkotmánybíróság a 3089/2019. (IV. 26.) AB határozatban elutasította a Fővárosi Ítélőtábla mint harmadfokú bíróság ítélete alaptörvény-ellenességének megállapítására és megsemmisítésére irányuló alkotmányjogi panaszt. 
4.2. Az alkotmányjogi panasz alapjául szolgáló ügyben az indítványozók több ismeretlen társukkal együtt hat pénzintézet ügyfélterében elhelyeztek egy-egy rózsaszínes színű papírba csomagolt fahasábot, amelyeknek egyik oldalára az „Elég volt a kifosztásból! Fordíts!” szöveget, míg a másik oldalára Petőfi Sándor Föltámadott a tenger című versének egy részletét írták. A becsomagolt fahasábokat a pénzintézetekben úgy helyezték el, hogy a vers szövege csak akkor vált láthatóvá, ha a csomagot valaki felvette és megfordította.

A járásbíróság ítéletében arra az álláspontra jutott, hogy a tények együttes értékelése alapján az elhelyezett tárgyak alkalmasak voltak arra, hogy robbanóanyagot tartalmazzanak. Az elsőfokú ítélettel szemben az indítványozók fellebbezést nyújtottak be a törvényszékhez, amely az indítványozókat az ellenük emelt vád alól felmentette. Végül az ítélőtábla az indítványozókat bűnösnek mondta ki közveszéllyel fenyegetés bủntettében, mivel az Ítélőtábla szerint a hat pénzintézet ügyfélterében elhelyezett becsomagolt fahasábok alkalmasak voltak arra, hogy azt a látszatot keltsék, hogy azok a személy- és vagyonbiztonságot veszélyeztetik.

Az indítványozók alkotmányjogi panaszukban kifejtették, hogy az ítélőtábla ítélete sérti a véleménynyilvánításhoz való jogukat. Úgy vélték, hogy jelen esetben alapvető alkotmányjogi jelentőségű kérdés, hogy egy véleménynyilvánítás esetében kerülhet-e sor bűncselekmény megállapítására, ha azt nyilvánvalóan alkalmatlan eszközzel követik el.

4.3. A testület az alkotmányjogi panaszt nem találta megalapozottnak. Az Alkotmánybíróságnak nem feladata annak eldöntése, hogy az eljáró bíróságok mely cselekményeket tekintik a társadalomra veszélyesnek. Azt azonban vizsgálni kell, hogy a társadalomra veszélyesség megállapítása nem eredményezi-e egy védett alapjog gyakorlásának alkotmányellenes korlátozását.

Az ítélőtábla szerint fennállt a személy- és vagyonbiztonság veszélyeztetésének látszata. Ezt a tényt az Alkotmánybíróság nem vizsgálhatja felül, ehelyett elsődlegesen azt kellett tisztáznia, hogy az indítványozók cselekményével kapcsolatban azonosítható-e a kommunikációs tartalom.

Az indítványozók a bírósági eljárásban kiemelték, hogy a becsomagolt, felirattal ellátott fahasábokkal a bankok - álláspontjuk szerint - embereket kifosztó politikája ellen kívántak felszólalni. A csomagoláson elhelyezett feliratok tartalma és azoknak a bankfiókok ügyfélterében történő felolvasása kétségtelenül kommunikációs tartalommal rendelkezik, egyúttal alkalmas az indítványozók által megjelölt üzenet kifejezésre juttatására. Kérdés ugyanakkor, hogy a megfogalmazott üzenet kifejezésének eszközéül elfogadható volt-e az indítványozók által választott megoldás - az ugyanis nem tekinthető a kommunikáció klasszikus formájának.

E vonatkozásban azonban azt is vizsgálni kell, hogy a véleményközlés személyes szándékán túl az indítványozók cselekménye objektív módon is alkalmas eszköze, közvetítője volt-e gondolatok közlésének. Ugyanis csak ebben az esetben vonható a cselekmény a véleménynyilvánítás alkotmányosan védett körébe. Ennek megíté- 
lése során pedig annak van különös jelentősége, hogy a konkrét cselekmény mind a „véleménynyilvánító” személy szubjektív szándéka, mind az objektív értékelés szerint - legalább hipotetikusan - a nyilvánosság előtt értelmezhető közlésnek tekinthetö-e.

A közlés objektív értelmezhetősége és a közbiztonság alkotmányosan védett értéke két olyan szempont, amelyek vizsgálata csak együttesen végezhető el. Az indítványozók cselekményének üzenete az ítélőtábla ítélete szerint azért nem volt a külső szemlélő számára egyértelműen azonosítható, mivel egyúttal alkalmas volt annak a látszatnak a keltésére, hogy a cselekmény a közbiztonságot veszélyezteti.

Bár az indítványozók cselekményének volt azonosítható kommunikációs üzenete, az összességében mégsem tekinthető védett alapjoggyakorlásnak, mivel az indítványozók cselekményének kommunikációs üzenete nem volt azonosítható a külső szemlélő számára. A vizsgált cselekmény sértette a közbiztonság fenntartásának alkotmányosan védett értékét.

Mindezek alapján megállapítható, hogy mivel a véleménynyilvánítás szabadságának védelmi köre nem terjedt ki a vizsgált esetre, a bíróság a cselekmény társadalomra veszélyességét sem zárhatta ki.

Mindezek figyelembevételével az Alkotmánybíróság megállapította, hogy az ítélőtábla a fentiekben rögzített szempontokat megfelelő módon értékelte, így az indítvány által támadott ítélet nem áll ellentétben az Alaptörvénnyel.

\section{Az életvitelszerü közterületen tartózkodás tilalma nem alaptörvény-ellenes, az államnak ugyanakkor a szankció alkalmazásakor fokozott körültekintéssel kell eljárnia.}

5.1. Az Alkotmánybíróság a 19/2019. (VI. 18.) AB határozatban kimondta: a szabálysértésekről, a szabálysértési eljárásról és a szabálysértési nyilvántartási rendszerről szóló 2012. évi II. törvény 178/B. \$-ának hajléktalan személyek esetében történő alkalmazása során az Alaptörvény XXII. cikk (2) és (3) bekezdéséből fakadó alkotmányos követelmény, hogy a szabálysértési szankció alkalmazására csak akkor kerüljön sor, ha a hajléktalan személy ellátórendszerben való elhelyezése a cselekmény elkövetésekor igazolhatóan biztosított volt. A szabálysértési szankció alkalmazásának meg kell felelnie az életvitelszerű közterületen tartózkodás tilalma alkotmányos céljának, az elesett, magukról gondoskodni nem tudó személyek ellátórendszerbe vonásának.

5.2. Az Alkotmánybíróság bírói indítványok alapján vizsgálta a szabálysértési törvénynek az életvitelszerű közterületen tartózkodás tilalmára vonatkozó szabályozását. Az indítványozó bírák az előttük folyamatban lévő egyedi szabálysértési ügyekben fordultak a testülethez és a támadott szabályozás alaptörvény-ellenességét állították. Az indítványozók az Alkotmánybíróságnak egy korábbi 2012-ben meghozott döntésére (amely döntésében az Alkotmánybíróság megsemmisítette a szabálysértési törvénynek a jelen ügyben alkalmazandó szabályozáshoz hasonló tényállását), továbbá 
arra hivatkoztak, hogy az Alaptörvénynek az életvitelszerü közterületen tartózkodást tiltó rendelkezése önmagában nem teszi indokolttá az életvitelszerü közterületi tartózkodás kriminalizálását. Az indítványozó bírók szerint a támadott rendelkezések a jogállamiság elvével és az emberi méltósághoz való joggal is ellentétesek.

Az Alaptörvény hetedik módosítása az Alaptörvénybe iktatta a XXII. cikk (2) és (3) bekezdését, amelynek következtében - az indítványozók által sem vitatottan - a vonatkozó alaptörvényi szabályozás alapvetően változott meg. Az alkotmányozó a legmagasabb jogforrási szinten, az Alaptörvényben vezetett be egy általános, mindenkire vonatkozó olyan tiltó rendelkezést, amely tilalmazza az életvitelszerű közterületen tartózkodást.

Az Alkotmánybíróság a határozatában úgy foglalt állást, hogy a megváltozott alaptörvényi szabályozásra tekintettel - amely a közterületen való életvitelszerủ tartózkodást mindenki számára általános jelleggel megtiltja - a 2012-es alkotmánybírósági határozat nem alkalmazható. Az Alkotmánybíróság az Alaptörvény hatályos szövegét tekinti irányadónak, az Alaptörvényt, illetve annak módosítását tartalmilag nem vizsgálhatja felül.

Az Alkotmánybíróság megkereste a belügyminisztert, az igazságügyi minisztert és az emberi erőforrások miniszterét, továbbá az érintett szakmai, illetve civil szervezeteket. A megkeresett intézményeknek és szervezeteknek alkotmánybírósági megkeresésére adott válaszaiban foglaltak alapján megállapította, hogy az állam az érintettek esetében jogilag szabályozott keretek között jelenleg is fenntart és múködtet egy szociális ellátó-, illetve intézményrendszert, és széles körben együttmúködik az önkormányzatokkal, az alaptevékenységük szerint ilyen tevékenységet ellátó vagy azt segítő társadalmi szervezetekkel és az egyházakkal is. Az érintettek számára rendelkezésre állnak nappali melegedők, éjjeli menedékhelyek, átmeneti szállások és a téli időszakban időszakos férőhelyek. A megkeresett civil szervezetek (közelebbről a Hajléktalanokért Közalapítvány és a Magyar Máltai Szeretetszolgálat Egyesület) szakmai állásfoglalásukban rámutattak arra, hogy azért tevékenykednek, hogy senkinek ne kelljen közterületen élnie és önálló lakhatás hiányában, a társadalmi integráció elősegítéséhez a meglévő intézményrendszer szolgáltatásai biztosítják az első lépéshez szükséges feltételeket. Mindebből az is következik, hogy az életvitelszerủ közterületen élés nem egy megváltoztathatatlan állapot.

Az Alkotmánybíróság a határozatában azt is hangsúlyozta, hogy az Alaptörvény emberképe nem az elszigetelt egyéné, hanem a társadalomban élő felelős személyiségé. Az egyén közösségben él, jogai, így alkotmányos jogai gyakorlása során is nemcsak önmagáért, de a közösség többi tagja iránt is felelősséggel tartozik; alkotmányos joggyakorlásának egyensúlyban kell állnia a közösség tagjaként a közösségért is viselt felelősséggel. Ennek az egyensúlynak a fenntartásához nélkülözhetetlen az együttmüködési kötelezettség teljesítése.

Az önrendelkezési jog, illetve a cselekvési autonómia nem terjed ki az alaptörvényi tilalom megszegésére, az Alaptörvényben tiltott magatartás választására, sem pedig szabálysértés elkövetésére. Az Alaptörvény értékrendje szerint a nincstelen- 
ségre, a hajléktalanságra senkinek nincs joga, ez az állapot nem az emberi méltósághoz való jog része. Az emberi méltósághoz való jogot súlyosan sérti az embernek az emberi társadalomból való kiszorulása, az emberi méltóság sérelmét azonban éppen az okozná, ha az egyént az állam magára hagyná. Az állam a segítségre szoruló, elesett, magáról gondoskodni képtelen személyt nem hagyhatja magára, ez az állami intézményvédelmi kötelezettség következik az Alaptörvény értékrendjéből, a szegények és elesettek védelmére vonatkozó állami kötelezettségből. Tehát éppen az okozna sérelmet, ha az egyént az állam magára hagyná anélkül, hogy gondoskodna róla, mivel az emberi méltósághoz való jogot súlyosan sérti az embernek az emberi társadalomból való kiszorulása. Az Alkotmánybíróság rámutatott, hogy az indítványozó bírók nem igazolták, hogy az ellátórendszert igénybe vevőket tárgyként kezelnék, vagy dehumanizálnák.

Az Alkotmánybíróság rámutatott arra, hogy az ügyben nem az emberi méltóság érinthetetlen „méltóságmagja”, hanem az önrendelkezési jog és a cselekvési autonómia, mint annak korlátozható része állt a vizsgálat középpontjában. Ebből nem következhet ugyanakkor sem valamely alaptörvényi tilalom megszegése, sem pedig szabálysértés elkövetése. Az Alaptörvény értékrendje szerint a nincstelenségre, a hajléktalanságra senkinek nincs joga, ez az állapot nem az emberi méltósághoz való jog része.

Egy alaptörvényi tilalom megszegését, tehát egy jogellenes magatartást az Alaptörvény nem védi. A határozat szerint a támadott szabályozás megfelel a szabálysértési jog alkotmányos követelményének, és érvényesíti annak garanciáit. A szabályozás mindazokkal szemben állapít meg szankciót, akik az erre irányuló alaptörvényi tilalom, illetve többszöri, kifejezett felhívás ellenére sem kívánnak felhagyni az életvitelszerủ közterületen tartózkodással. A támadott tényállás tehát nem egy állapotot (a hajléktalan létet) szankcionál, hanem az együttműködési kötelezettség megsértéséhez füz jogkövetkezményt.

Emellett az Alaptörvényből az állam fokozott intézményvédelmi kötelezettsége következik. Ezt úgy tudja ellátni, ha az érintett személyeknek az ellátórendszerbe való bekerüléséről gondoskodik. Az egyén együttműködésének hiányában ugyanis csak a szabálysértési szankció mint végső eszköz áll az állam rendelkezésére. Az Alkotmánybíróság ugyanakkor alkotmányos követelményként kimondta, hogy a szabálysértési szankció csak akkor alkalmazható, ha a hajléktalan személy ellátórendszerben való elhelyezése a cselekmény elkövetésekor igazolhatóan biztosított volt. A jogalkalmazó szerveknek emellett figyelemmel kell lenniük az elesettek védelmére irányuló alkotmányos kötelezettségre, másrészt arra is, hogy az érintettek jogainak védelme csak az ellátórendszerbe történő bekerülésükkel biztosítható.

A határozathoz Pokol Béla alkotmánybíró párhuzamos indokolást csatolt, míg Czine Ágnes, Juhász Imre, Hörcherné Marosi Ildikó, Schanda Balázs, Stumpf István és Szalay Péter alkotmánybíró különvéleményt füzött. 


\section{C)}

\section{Strasbourg: az Emberi Jogok Európai Bíróságának eljárását megelözöen - amennyiben egy ügyben alkalmas a jogsérelem orvoslására - az alkotmányjogi panasz lehetöségét ki kell meríteni}

Az alkotmányjogi panasz intézményének történetében fontos állomást jelent, hogy a strasbourgi Emberi Jogok Európai Bírósága (a továbbiakban: EJEB) igennel válaszolt arra a kérdésre, hogy az Alkotmánybíróság elé terjeszthető alkotmányjogi panasz hatékony jogorvoslatnak minősül-e. Ha tehát egy ügyben az alkotmányjogi panasz alkalmas eszköz a jogsérelem orvoslására, akkor az Alkotmánybíróság előzetes eljárása a feltétele annak, hogy egy indítványozó az Emberi Jogok Európai Bíróságához fordulhasson.

A Szalontay v. Magyarország $g^{3}$ ügyben egy budapesti szórakozóhely volt tulajdonosa azért nyújtott be indítványt a strasbourgi Emberi Jogok Európai Bíróságára, mivel álláspontja szerint a magyar hatóságok megsértették a tisztességes eljáráshoz való jogát. Véleménye szerint sérült a fegyverek egyenlőségének elve és a pártatlan ítélkezéshez való joga. Az EJEB nem találta érdemben elbírálhatónak a beadványt, mivel a tisztességes eljáráshoz való jog az Alaptörvényben biztosított jog, a kérelmező pedig az ügyben nem nyújtott be alkotmányjogi panaszt az Alkotmánybírósághoz azt megelőzően, hogy a strasbourgi szervhez fordult volna.

Az EJEB eljárásának feltétele, hogy a kérelmező merítse ki az összes hazai, úgynevezett hatékony jogorvoslati lehetőséget. A döntés szerint az ügyben az Alkotmánybíróságról szóló 2011. évi CLI. törvény (a továbbiakban: Abtv.) 26. $\mathbb{S}$ (1) bekezdése alapján a kérelmező megtámadhatta volna a bírói ítéletben alkalmazott jogszabályt, illetve az Abtv. 27. \$ szerinti alkotmányjogi panasszal élve megtámadhatta volna a bírói ítéletet. Az alkotmányjogi panasz fajtái tehát hatékony jogorvoslatnak tekinthető lett volna az EJEB szempontjából, ezért ki kellett volna őket meríteni az eljárás megindításához. Mindez azt jelenti, hogy ha egy ügyben az alkotmányjogi panasz alkalmas eszköz a jogsérelem orvoslására, akkor az Alkotmánybíróság előzetes eljárása a feltétele annak, hogy egy indítványozó az EJEB-hez fordulhasson. ${ }^{4}$

3 71327/13., 2019. március 12., a döntés összefoglalása angol nyelven elérhető ezen a linken: https:// hudoc.echr.coe.int/eng\#\{\%22itemid\%22:[\%22002-12426\%22]\} (2019. 07. 01.)

4 Az Emberi Jogok Európai Bíróságának összefoglalója itt érhető el: https://hudoc.echr.coe.int/eng\#$\{$,itemid”:[„002-12426”]\} (2019. 07. 01.) 